\title{
Climate Change and the Convention for Biological Diversity
}

The Convention on Biological Diversity has increasingly allowed itself to be influenced by business interests in recent years, at the expense of ensuring a democratic equitable process.

This has exposed the Convention to proposals to adopt a number of false solutions that perpetuate biodiversity destruction, climate change and erosion of people's rights, especially those of women, indigenous peoples and local communities. Healthy ecosystems and biodiversity are vital for regulating the climate. False climate solutions that harm biodiversity, communities and ecosystems will further destabilize the climate. They also result in the displacement of, and the loss of rights of indigenous peoples and local communities.

We are already witnessing such severe impacts, as the result of false solutions that are currently being implemented on a large scale: agrofuel (also called biofuel) crops, and industrial tree plantations, which UN bodies falsely refer to as 'afforestation and reforestation' To make matters worse, certification schemes, standards and criteria falsely promote these damaging activities as being 'environmentally sustainable'. A range of other false solutions have also been proposed and some of them are already beginning to be implemented. These also threaten to have grave impacts on biodiversity, climate stability and the rights of people. They do not address the root causes of climate change but have the potential to worsen the crisis, and include:

Genetically engineered trees for industrial tree plantations that will be used as agrofuels and 'carbon sinks'; Ocean-'fertilization' (e.g., dumping iron particles in the sea) Carbon Capture and Storage (CCS):This includes fossil fuel combustion with CCS and bioenergy with CCS; Soil carbon sequestration schemes linked to industrial agriculture. Corporations are also promoting false solutions for climate change adaptation. Those include genetic engineering, using patented genes to induce resistance in crops to drought, salinity and extreme temperatures.

At a time when rampant free market capitalism has led to financial crisis, with skyrocketing oil and food prices, market based 'innovative' financial mechanisms are still being promoted to commodify nature including, carbon trading, carbon offsets, payments for environmental services, reducing emission from deforestation and degradation (REDD)and biodiversity offsets. These 'solutions' are more likely to endanger biodiversity, climate and communities. Such false solutions are really for the benefit of corporations. The real agenda behind this is to increase corporate control over land, forests, water, agriculture and biodiversity, using climate change and the biodiversity crisis as an opportunity to further these objectives. This is a new 21st century phase of colonialism. These false solutions are facilitated by false definitions and language: For example, tree plantations are referred to as 'forests' and intensive industrial agriculture is called a 'Green Revolution'.

We call on the international negotiators and representatives of the different sectors and NGOs at CBD COP9 to oppose any intent to water down the Convention and perpetuate corporate interests. They must reject GE trees, industrial agrofuels and plantations, carbon trading and offsets, ocean fertilization, climate ready genes, another destructive 'Green Revolution' and any other false solution that ignores and harms community rights, including those of indigenous peoples, degrades ecosystems, and constitutes a threat to biodiversity and climate.

African Biodiversity Network

Africa Europe Faith and Justice Network

A SEED Europe

Biofuelwatch, UK

Carbon Trade Watch

CEPPAS

CORE, India

Corporate Europe Observatory,The Netherlands

ETC Group, Canada

FASE-ES, Brazil

Focus on the Global South

Friends of the Earth, Mauritius, Papua New Guinea -

Centre for Environmental Law,

Costa Rica - COECOCEIBA, Australia, Denmark - NOAH

Gaia Foundation, UK

Global Forest Coalition

Global Justice Ecology Project, USA

Grupo de Reflexión Rural

Indigenous Environment Network
Intercultural Resources, Lokayan, India International Indian Treaty Council

Kalikasan People's Network for the Environment, Philippines

Movimientos Madre Tierra, Honduras

National Forum of Forest People \& Forest Workers, India

Oilwatch International

Peoples Forum against ADB

RAPAL, Uruguay

River Basin Friends (NE), India

School of Democratic Economics, Indonesia

Sobrevivencia, Paraguay

SOLJUSPAX, Philippines

Stop GE Trees Campaign

Sustainable Energy \& Economy Network, USA

Terra de Direitos, Brasil

The Cornerhouse, UK

Timberwatch Coalition, South Africa

Transnational Institute, The Netherlands

World Rainforest Movement, Uruguay 